\title{
DIE UITDAGING VAN DIE NATUURWETENSKAP IN ONS TYD
}

Gedurende die eerste 50 jaar van hierdie eeu het die natuurwetenskappe meer bereik as gedurende al die eeue van die menslike bestaan. Die mens se gemiddelde lewensverwagting is met 20 jaar opgestoot en hy het tot sy beskikking gekry elke denkbare meganiese en elektroniese fasiliteit vir sy gemak en gerief en hy beskik oor kommunikasiemiddels wat aan die begin van hierdie eeu as onmoontlik beskou is. Dit is byna ' $n$ versoeking om te wil byvoeg dat die afgelope 20 jaar se natuurwetenskaplike ontwikkeling en vordering dié van die voorafgaande $\mathbf{5 0}$ jaar in die skadu stel. Die afgelope twee jaar alleen het twee hoogtepunte in hierdie natuurwetenskaplike prestasiewedloop gelewer wat alle ander op die agtergrond geskuif het - ek verwys hier na die eerste geslaagde oorplanting van 'n menslike hart en die eerste suksesvolle maanvlug. Voeg ons hierby die vooruitsig om eersdaags mense op die maan te land, kernkrag vir die ekonomiese opwekking van elektrisiteit en die grootskaalse ontsouting van seewater, weervoorspellings van weke vooruit, reusestralers $(1,000$ passasierklas $)$ teen klanksnelheid, laserstrale wat 100-miljoen telefoonoproepe en 10-miljoen televisiekanale gelyktydig kan dra, en u sal saamstem dat ons 'n soort natuurwetenskaplike rewolusie belewe.

As dit onmoontlik geword het vir enige natuurwetenskaplike om tred te hou met die vakliteratuur en al die ontwikkelings op sy eie vakgebied en dit vir hom buite die kwessie is om by benadering kennis te dra van die snelle vordering op al die verwante vakterreine - hoe moeilik moet dit nie vir diegene buite hierdie vakgebiede wees om te verstaan wat die natuurwetenskaplike wil en waarheen hy op pad is nie? Begryplikerwys word dit vir hierdie twee groepe al hoe moeiliker om mekaar se taal te verstaan.

\section{Die era van die ,groot wetenskap"}

By gebrek aan 'n beter terminologie word vandag verwys na sommige van voorgenoemde aktiwiteite as sogenaamde Groot Wetenskap. Dit is 'n tipiese Amerikanisme en kan ewe goed dui op die reuse geldbedrae wat betrokke is, die oormatige aansprake, of die oordrewe omvang waartoe die lekepers 
hierdie dinge opblaas om die publiek of te imponeer of te ontnugter sonder dat die werklike natuurwetenskaplike betekenis daarvan enigsins begryp of in perspektief gestel word. Dit is die soort programme waaraan net lande kan deelneem wat bereid is om miljoene te spandeer en oor soveel vakkundige mannekrag beskik dat die voordelige aanwending daarvan nie 'n oorweging is nie. Dit ontaard in die reël in 'n prestigewedloop waar mislukking ' $n$ nasionale vernedering kan word en onttrekking vanweë finansiële onvermoë, 'n regeringskrisis kan veroorsaak. 'n Paar voorbeelde sal dit illustreer:

Die eerste vind ons op die gebied van Ruimtenavorsing. Daar word bereken dat die jongste geslaagde maanvlug alleen 200-miljoen dollar gekos het en die voortgesette program en uiteindelike landing op die maan sal moontlik twee na drie maal meer kos. Indien hierdie vlug nie geslaagd was nie en die ruimtevaarders met hul lewe geboet het, sou die ganse wêreldpers die Amerikaanse Maanprogram verdoem het as voorbarig, ongeregverdig en onverantwoordelik maar - "nothing succeeds like success". Ongelukkig het ons nie syfers vir die Russiese teenprestasie nie - ons kan aanvaar dit sou ewe astronomies wees. Van die hoeveelheid diepgaande navorsing wat agter hierdie prestasie sit, kom weinig onder die openbare aandag en, indien wel, sou meeste daarvan nie na waarde beoordeel kon word nie en afgeskryf word as te basies of te teoreties en in elk geval van geen sigbare ekonomiese nut nie. Wat die volle implikasies van 'n suksesvolle maanlanding, afgesien van prestigewaarde, inhou is vir die meeste van ons tans blote spekulasie - hierna verwys ek later weer.

'n Tweede voorbeeld kry ons uit die gebied van die kernfisika. Kernfisika was die afgelope twintig jaar die natuurwetenskaplike dissipline wat seker die meeste openbare belangstelling geniet het, honderde miljoene aan kapitaal geverg het en seker wêreldwyd van die beste breinkrag getrek het. Dit het die verbeelding van byna elke skoolseun wat in die natuurwetenskappe wou studeer gaande gemaak. Dit dien net terloops opgemerk te word dat daar tans sonder voldoende waarskuwing of goeie rede skielik stemme opgaan dat daar 'n oorproduksie aan kernfisici is, dat kernfisiese navorsing uitgeput sou wees en dat dit nou die terrein van die Ingenieursontwikkelingsbedryf is. Om egter op die gebied van kern- 
fisiese navorsing 'n verdere betekenisvolle bydrae te wil maak, sal ons baie kragtiger fasiliteite benodig as waaroor ons tans beskik en dit sal ook in ons eie land groot geld en wysheid in navorsingsbeleid verg.

In Europa het 'n konsortium van 'n aantal groot lande besluit om 'n sentrale fasiliteit vir ultra-hoë-energie kernfisika daar te stel, die sogenaamde $300 \mathrm{GeV}$. CERN-projek, waarvan

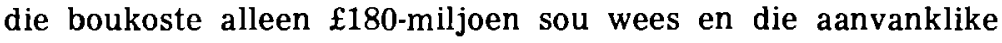
lopende koste byna $\mathfrak{1} 20$-miljoen. Engeland (met 'n aanvanklike f50-miljoen aandeel) moes noodgedwonge om finansiële redes hom hieraan onttrek en sy regering van die dag in 'n ernstige politieke verleentheid plaas, terwyl van die ander deelnemers nog huiwer om die finale sprong te waag. 'n Soortgelyke projek in Kanada (ING - Intense Neutron Generator) wat teen 155miljoen dollars gebou en teen 'n jaarlikse lopende koste van 20-miljoen dollars bedryf sou word en aan hom die leierskap op hierdie gebied sou besorg, is pas gekanselleer weens gebrek aan staatsteun.

Onlangs het $d r$. Glen T. Seaborg, voorsitter van die Amerikaanse Atoomkragkommissie, in vooruitsig gestel die „Nuplex" - agro-industriële komplekse wat deur een of groepe kernreaktors bedien sal word, wat genoeg elektrisiteit en water sal voorsien vir huishoudelike, besproeiings-, landboukundige en nywerheidsdoeleindes om 'n ,gemeenskap" van 100,000 boere, plaasarbeiders en fabriekslui en hul gesinne te onderhou, om genoeg voedsel te produseer om 5-miljoen ander mense te voed en les bes wat genoeg bemestingstowwe sal produseer om elders ander kos te produseer vir 'n verdere 50-miljoen mense.

Tans is 'n program in wording vir die eksplorasie en eksploitasie van die minerale en biologiese bronne van die diepsee - die beoogde program sal heet die Internasionale Dekade van die Diepsee. Alreeds beloop die Amerikanse beramings vir hierdie onderneming en sy voortsetting baie miljoene en word dit geplaas as net tweede na die Ruimteprogram met aansprake vir die huidige jaar alleen op 450-miljoen dollar, ten spyte van besnoeings in alle programme. Hierdie tipe "groot" wetenskap skep by die publiek meermale verwarring en 'n totaal verkeerde beeld van die natuurwetenskaplike se doel en strewe, sy vermoë en sy lewensbeskouing. Die doelwit van hierdie programme is hoofsaaklik nasionale selfbehoud en verdediging, en deur die toegangsprys hoog te maak is dit gewoonlik die 
maklikste metode om ongewenste medewerkers uit te hou.

Die natuurwetenskaplike van ons dag is terdeë bewus daarvan dat hy met sy navorsing ook die magte vir sy eie vernietiging daargestel het en is nie onverskillig ten opsigte van die ingewikkelde ekonomiese en maatskaplike probleme wat die natuurwetenskaplike ontwikkeling van die afgelope dekades geskep het nie. Of die sosioloë en ekonome opgewasse of bereid is om hierdie uitdaging te aanvaar, is ' $n$ ander saak. Die bewerings dat die natuurwetenskap ' $n$ bedreiging van die bestaande orde is, dat dit deur sy prestasies oorbeklemtoon word en ongeregverdig bevoordeel word, dat dit 'n oorverheerliking van die mens meebring en die almag en alwysheid van die Skepper uitdaag, kan ek nie ongekwalifiseerd aanvaar nie. Met al die fenomenale vooruitgang op die verskillende natuurwetenskaplike terreine in ons tyd, is ons maar slegs besig om aan die buitenste skilletjie van die skeppingswonder te krap en by baie fondamentele vraagstukke tas ons nog in die duister rond.

\section{Die natuurwetenskap en die gemeenskap}

Daar is haas geen terrein van die natuurwetenskap waar die vordering so betekenisvol was soos juis op die biologiese gebied nie. Soos reeds gesê is die lewensverwagting van die mens met 20 jaar opgestoot - dit bly eenmaal so dat hoe groter die probleme op hierdie tranedal van ons word, hoe traer is die mens om van hom afskeid te neem. Omdat die mens gemiddeld ouer word, het dit op sigself ernstige sosiologiese probleme geskep soos oorbevolking, ondervoeding, behuising, gesondheid, groter produksie per eenheid oppervlakte, beveiliging van oeste en veestapel teen siektes, peste en plae.

Pas 100 jaar gelede het chloroform as nakotikum pynlose chirurgie moontlik gemaak, sestig jaar gelede is die eerste onderhuidse inspuiting aan 'n mens toegedien en 35 jaar gelede is die eerste antibiotikum toegedien met die verskyning van die M \& B reeks - sedertdien was die ontwikkeling op hierdie gebied verbysterend en is soveel heilmiddels, hulpmiddels, stimuleermiddels, kalmeermiddels en onnodige middels vir die mens se gerief, gesondheid en ontvlugting gemaak dat daar vir ' $n$ enkele fisieke toestand, soos kyvoorbeeld moegheid, alleen 160 middels op die mark is. Talle van hierdie middels is vandag op die gevaarlys as verslawend, giftig of die oorsaak van 
'n duisternis ander siektetoestande. Fundamentele navorsing oor die fisiologie en toksikologie van baie van hierdie middels is nog nie eers gedoen teen die tyd dat hulle al klaar uitgedien of op die gevaarlys geplaas is nie. Die gejaagde mens van vandag is haastig en wil onmiddellike resultate sien, ongeag die konsekwensies vir hom of sy nageslag - dit het ons ervaar met die berugte thalidomied-behandeling. Soos ons dan 'n gevoeligheid en uiteindelik lewensgevaarlike reaksies ontwikkel teen hierdie potente heilmiddels, word die farmaseutiese en chemiese wetenskappe voortdurend voor nuwe uitdagings geplaas om kragtiger en hopelik veiliger surrogate te soek. En as u ook dalk af en toe lus voel om mee te doen aan die koor wat hul stem verhef teen hierdie kunsmatige ,instandhouding" van die menslike liggaam, wag dan eers totdat $u$ aan eie liggaam gekonfronteer word met 'n situasie waar menslike hulp nie verder kan nie, en u sal self in desperaatheid na enige redmiddel gryp.

Dit pas om in hierdie stadium te verwys na die geslaagde hartoorplanting waarna reeds verwys is. Vir die mediese wetenskap en vir Suid-Afrika in die geheel was dit 'n besondere prestasie en het dit 'n klimaat geskep waar groter begrip en waardering vir navorsing die beurse laat oopgaan het. Indien dit 'n minder sleutelorgaan as die hart sou wees wat oorgeplant was, sou dit maar 'n relatief floue openbare reaksie ontlok het, en as ons medici nie hierdie prestasie binnekort opvolg met iets meer dramaties nie, sal die gunstige klimaat om fondse vir mediese navorsing te bekom baie gou verby wees.

Hartoorplanting het egter binne die kort bestek van twee jaar 'n prestige-wedloop op internasionale vlak geword soortgelyk aan die maanvlug, en elk groot hospitaal en hartchirurg is daarop ingestel om minstens een hart te kan oorplant - of die pasient nou 5 minute, 5 maande of uiters 5 jaar langer gaan lewe voordat die orgaan verwerp gaan word, is nou van sekondêre belang en van nog minder belang die feit dat dit voorasnog geen algemene chirurgiese praktyk kan word nie vanweë die skaarste aan gesonde harte, om voorlopig van finansiële en etiese implikasies te swyg. Desnieteenstaande word miljoene ingesamel vir orgaanoorplanting, terwyl belangrike voorvereiste basiese navorsing oor degenerasiesiektes en immunilogie nie die nodige finansiële steun kry nie, omdat hierdie begrippe moeilik is om aan die publiek te "verkoop". Dit is veelseggend 
dat ' $n$ bekende hoogleraar in die chirurgie na aanleiding van grootskaalse eksperimentasie met orgaanoorplanting op primate die sonderlinge erkenning moes maak dat ons nou voor die probleem te staan gekom het dat ons die verwerpingsverskynsel ook hier nie kan begryp nie, omdat ons nie genoeg weet van die biologie van die bobbejaan nie.

Op die gebied van die landbou en veeteelt het daar soveel insek-, parasiet- en plantdoders verskyn om as plaasvervangers te dien vir die indertydse gevaarlike arseenvergifte, dat dit nouliks moontlik is om enigsins by te hou met die nuwes wat daagliks op die mark verskyn - laat alleen om te weet dat alles beskikbaar is. Laat ons ruiterlik erken dat sedert 1940 met die verskyning van die gechloreerde koolwaterstowwe (DDT en BHC) sekere insekplae en daarmee die siektes wat hulle dra, so verdryf is dat groot gebiede in ons eie vaderland aan die landbou oopgestel kon word - ek verwys hier na die muskiet en malaria, die tsetsevlieg en ngana en die bekamping van die spinkaanplaag. Maar die insekte het begin bestand word hierteen, en kragtiger middels moes voortdurend gevind word, sodat ons vandag opgeskeep sit met hoogstoksiese insekdoders waarmee ons ons landbougewasse moet beskerm. Nou reeds weet ons dat al hierdie vergifte in die landbouprodukte opbou tot konsentrasies wat vir die menslike gesondheid hoogs gevaarlik is en dat dit in sommige van ons vrugte reeds so hoog is dat dit ' $n$ wesenlike probleem is vir sover dit ons vrugteuitvoerhandel betref. Dit is bekend dat selfs die pikkewyne in die subantarktiese eilande reeds 'n gevaarlike konsentrasie DDT in hul liggame opgebou het, dat baie van ons roofvoëls alreeds 'n hoë persentasie kwik bevat via die knaagdiere wat leef van saadgraan wat teen swamsiektes met organiese kwikverbindings behandel word. Ons damme en riviere word besoedel met dieldrin en dergelyke gifstowwe wat aangewend word by die lugbespuiting van graanlande teen luise en weiveld teen termiete. Haastige wetgewing word tans oral ingedien teen die gebruik van hierdie middels en die bioloë en chemici moet terug na hul werkplekke om minder gevaarlike middels te soek - nuwe rigtings soos biologiese bestryding deur middel van sekslokstowwe en sterilante en selfs massabestraling word aan gedink, maar die tyd moet leer of dit prakties geslaagd gaan wees. Op die gebied van die veeteelt het ons eweneens ernstige gesondheidsprobleme geskep deur die onbeheerde ge- 
bruik van antibiotika en hormone nie slegs vir die bestryding van veesiektes nie maar ook in rantsoene van melk-en slagvee. Dit is geen geheim meer nie dat hierdie praktyk reeds ernstige gesondheidsrisiko's inhou vanweë die ontwikkeling in die mens van lewensgevaarlike oorgevoeligheid teen hierdie stowwe en van antibiotiesbestande organismes wat siektes van die verlede soos maagkoors en longontsteking tans net so dodelik gevaarlik maak soos voorheen.

Samevattend kan ons sê dat met al ons ontwikkeling, ons ons eie omgewing so besoedel het dat die heil wat ons vir die mensdom gebring het, nie opweeg teen die nuwe gevare waaraan ons hom uitgelewer het nie en tog - daar is geen terugkeer na die sogenaamde ou weë nie. Dok op hierdie gebied is ons steeds voor nuwe uitdagings en sal besigheidsoorwegings steeds die natuurwetenskaplike- onder openbare druk plaas om beter te presteer sonder voldoende voorsiening aan tyd of geld om dieper te kan dring tot die kern van die probleem, naamlik die geheimenisse van die funksionering van die lewende sel na my beskeie oordeel die grootste uitdaging vir die natuurwetenskap van ons dag. Met die sintese van DNA en 'n beter begrip van die geheim van die genetiese kode, het ons nader gekom aan die wese van die genetiese ingewikkeldhede van die menslike samestelling. Terwyl ons met die beste breinkrag sukkel om hierdie ingewikkeldhede te begryp en die skade wat vreemde stowwe hier aanrig te probeer opvolg en te bepaal, word sulke behandeling bepleit soos grootskaalse bestraling van voedsel vir preservering, kweek van nuwe plantsoorte deur verandering van die gene deur bestraling ens. - alles oppervlakkige en moontlike selfs uiteindelik noodlottige praktyke, omdat ons gebrek aan diepgaande kennis oor hierdie aangeleentheid nie voldoende verweer is teen kommersiële druk nie.

Miskien is die stelling waar dat ons tegniese prestasies en die tegnologiese ontwikkeling van ons tyd ons denke en wysheid op maatskaplike en politieke gebied te ver voor is, maar wat onbetwisbaar waar is, is dat die natuurwetenskappe voortdurend nuwe uitdagings in die gesig sal moet staar vanweë die maatskaplike probleme wat sy eie vordering skep.

\section{Die balans tussen navorsing en ontwikkeling}

In die natuurwetenskaplike ontwikkelingsprogram erken 
ons in die reël drie fases - basiese of fundamentele navorsing, toegepaste navorsing en laastens ontwikkeling. Die ontwikkelingsgedeelte is die duurste aan geld en tyd, want dit behels die opskaling van laboratoiumresultate na bedryfseenheidgrootte vir die ekonomiese en effektiewe inbedryfstelling. Dwarsdeur die Westerse wêreld is die verhouding tussen geldvoorsiening vir hierdie drie komponente min of meer dieselfde, te wete $10 \%$ basies; $25 \%$ toegepas en $65 \%$ ontwikkeling. Laasgenoemde word verder verdeel volgens die behoeftes van elke land - so byvoorbeeld vind ons die verhouding Verdediging : Omgewingswetenskappe (gesondheid, behuising ens.) in die V.S.A. $85: 8$. Dis egter by die eerste twee komponente waar die probleem lê en waar, soos ek weldra sal aantoon, 'n universiteitsprobleem na vore kom. Nie een van ons ontwikkelingsprogramme kan slaag sonder dat die fondamentele navorsing behoorlik aandag kry nie. Nou is dit so dat die toegepaste navorsing vir die openbare sektor makliker sigbaar en verstaanbaar is en van meer onmiddellike nut. Handelsbelange en besigheidsoorwegings kan derhalwe maklik hierdie komponent so beinvloed en oorbeklemtoon dat fondamentele navorsing moet ly en plek maak vir oppervlakkigheid bo diepsinnigheid, waar ons meer begaan is oor ' $n$ haastige oplossing van die probleem, al is die antwoord ook soms onjuis of dikwels gevaarlik. Dis in hierdie sektor waar die meeste kwaad gedoen word wanneer finansiële druk die inkorting van programme noodsaak - die inkorting is eerste by die basiese komponent, want vir die beursdraer is dit die moeilikste om te begryp en te waardeer en beskou hy dit derhalwe as luuks en iets waarsonder ons wel sal klaarkom. Dit kan lei tot ontsettende frustrasie omrede die fondamentele ondersoek tot groot hoogte die terrein van die universiteitsnavorser is, die program waarmee ons die natuurwetenskaplike van môre moet oplei. In sy geheel gesien is toegepaste navorsing die terrein van nywerheidsinstitute en beklee dit geen prominente plek in die universiteit nie.

Die relatiewe waardes wat soms geheg word aan fundamentele versus toegepaste navorsing word deur die volgende voorbeeld uit die ruimtenavorsingsprogram geillustreer: So pas het dit aan die lig gekom dat van die senior administrateurs en navorsers in die basiese wetenskappe by die maanvlug-ruimteprogram in die V.S.A. bedank het omdat hulle hul verdere teenwoordigheid as oorbodig en sonder enige vakkundige betekenis 
beskou. Deur besnoeiing van die NASA-program is geen beperkings geplaas op die prestigewedloop om eerste op die maan te stap nie - maar geen verdere fundamentele fisiese en geochemiese studies oor die maanoppervlak of fisiologiese ondersoek op maanreisigers sal gedoen word nie. Intussen is Amerikaanse en Russiese genetici besorgd oor die hoë voorkoms van mutasies, chromosoombeskadiging en versteuring van sel-verdelingsmeganismes by ruimtevaarders - skade wat nie aan kosmiese strale toegeskryf kan word nie.

\section{Natuurwetenskaplike opleiding aan ons universiteite}

Teen die agtergrond van die voorafgaande voel die basiese natuurwetenskappe aan ons universiteite hulself meermale op die kruispad.

Weens die groter klem op en die openbare belangstelling vir toegepaste navorsing, is dit moeiliker om fondse vir die meer basiese navorsing na die universiteite te trek, terwyl toegepaste navorsing vir universiteite te duur is. Maar toegepaste navorsing kan nie sonder die basiese bedryf word nie, en dus verskuif ook 'n deel van basiese navorsing uit die universiteit. Aangesien toegepaste natuurwetenskappe en veral die professionele rigtings soos medisyne, ingenieurswese ens. die moontlikheid van groter finansiële vergoeding inhou, vind die verskuiwing van belangstelling weg van die meer basiese rigtings plaas, en dit geld vir die grootste deel van ons heel begaafdste studente.

Weens die snelle vordering op al die terreine van die basiese natuurwetenskappe word die eise in hierdie vakke al hoër en word dit al moeiliker om in die strawwe kompetisie ' $n$ betekenisvolle bydrae te lewer. Daarbenewens vind ons nou dat, die hoë eise van hierdie vakke ten spyt, baie van hierdie goedgekwalifiseerdes in die basiese wetenskappe dit moeilik vind om betrekkings te bekom waarvan die vergoeding enigsins gunstig vergelyk en derhalwe noodgedwonge na die toegepaste of selfs die handels- en administratiewe rigtings uitwyk.

Daar is vandag ' $n$ wêreldwye tendens van ' $n$ verskuiwing van die natuurwetenskaplike na die geesteswetenskaplike rigtings en binne die natuurwetenskappe self 'n klemverskuiwing ten gunste van die biologiese rigtings, hoofsaaklik vanweë 'n ontvlugting aan die hoër eise van veral die wiskundige weten- 
skappe. Hierdeur word die opleiding van eersterangse bioloë belemmer en navorsing op die gebied gestrem, want om in ons tyd ' $n$ betekenisvolle bydrae op die fisiologies/chemies-fisiese terreine van die biologie te maak, vereis 'n baie deeglike onderlegdheid in die matematiese wetenskappe.

Die vraag ontstaan watter tipe navorsing die universiteitsdosent met vrug behoort te onderneem, of hy hoegenaamd navorsing moet onderneem en of hy ooit met sy beperkte personeel en finansiële ondersteuning ' $n$ noemenswaardige bydrae kan maak. Dit is 'n onomstootlike feit dat die beste navorsing gedoen word deur groepe of skole in 'n bepaalde vakgebied. Ewe waar is dit dat navorsing in die natuurwetenskappe duur is. Ons beskik vandag oor kragtige fasiliteite wat die werk van jare na maande en dae selfs kan verkort - in my eie vakgebied is dit geen oordrywing dat 'n probleem wat 'n dertig jaar gelede pragtige geleentheid was vir 'n doktorale studie oor 'n drie jaar (sonder om noodwendig ' $n$ antwoord te lewer) met vandag se apparaat heelwaarskynlik 'n magisterstudent nie vir 3 maande sal besig hou nie. Hierdie versnelling eis sy tol aan geld. Dertig jaar gelede was apparatuur van die R50,000prysklas ' $n$ rariteit en in elk geval byna 'n hele universiteit se fondstoekenning - vandag is dit die prys van instrumentasie wat nie eers meer as juis navorsingsapparaat beskou hoef te word nie - inderwaarheid verander navorsingsapparaat binne 5 jaar vandag na opleidingsapparaat. Dit bring my dan onmiddellik by die volgende waarheid omtrent universiteitsnavorsing - dit is vir die oorgrote gedeelte aan ons universiteite niks anders nie as die opleidingsmetodiek vir gevorderde graadstudie. As ons anvaar dat die toeken van die hoogste akademiese grade aan ons universiteite 'n funksie is waarsonder die universiteit baie van sy status en prestige sou inboet, dan is dit gebiedend dat die universiteite in staat gestel word om die volle finansiële implikasies te kan nakom vir die voltydse opleiding van ons studente tot by die hoogste akademiese vlak. Dit gee aan 'n universiteitsdosent die grootste uitdaging maar ook die grootste voldoening. Om hierdie grade toe te ken aan mense wat die werk buite die laboratoria van u eie universiteit onder die toesig van persone of instansies buitekant die universiteit uitvoer, mag met gradedag indrukwekkend lyk, maar hou vir die betrokke universiteitsdepartement baie gevare in - die grootste dié van vakkundige aftakeling. Die eksperimentele natuurweten- 
skappe veral kan slegs op sy beste beoefen word onder die direkte leiding van 'n toegewyde en bekwame dosent wat bereid is om saam met sy studente die uitdagings aan te durf - dit is beslis vir so 'n student 'n geestelike bate wat hy buitekant die universiteit nie sal vind nie.

Die ontsettende groei in die volume van die vakliteratuur dwing die natuurwetenskaplike van ons dag tot al enger spesialisasie. Dit is in sigself geen fout nie. Ons moet gespesialiseerd kan dink voordat ons globaal kan dink en evalueer - andersom werk dit nie.

Alle navorsing aan universiteite, fundamenteel of toegepas, is goed solank as dit dissiplinêr korrek en verantwoord is. Fundamentele navorsing is die moeiliker navorsing, maar dit bereik alles wat nodig is - dit leer ons swaarkry, dink en konfronteer ons voortdurend met die beperktheid van ons menslike kennis en vernuf en stel ons in die regte verhouding tot ons Skepper. Dit is alles essensiële voorvereistes vir vakkundige en geestelike dissipline en die voortbring van nuwe idees, waarsonder sowel natuurwetenskaplike navorser, nyweraar en leier moeilik 'n staanplek in ons gekompliseerde gemeenskap kan verower.

\section{Die natuurwetenskap en die geesteswetenskappe}

Die natuurwetenskap en die geesteswetenskappe kan nie los van mekaar ontwikkel nie. Daar is reeds gewys op die geweldige sosiale, politieke en ekonomiese implikasies wat die natuurwetenskaplike ontwikkeling oor die afgelope aantal dekades geskep het. Ten spyte van al die prestasies en die behoeftes van nuwe tegnieke en tegnologiese ontwikkeling, staan die wêreld voor steeds groter-wordende probleme van oorbevolking, omgewingsbesoedeling, toenemende ongelykheid in ekonomiese voorspoed tussen ontwikkelde en ontwikkelende lande en is ontevredenheid, oproer en oorlog nog steeds aan die orde van die dag. Ons neem ernstig kennis van die huidige tendens van studenteverset en ontevredenheid wat oorgaan in anargie. Dit wek kommer dat die leiding vir hierdie opstand juis uit die geledere van die geesteswetenskappe kom - asof by gebrek aan oorredingsvermoë of roepingsbewustheid dié mense die sosiale orde met geweld wil verander, so asof dit 'n manier is om aandag op hulle te vestig. Die snelle ontwikkeling op 
die verskillende terreine van die natuurwetenskap waarna verwys is, oorheers tans so die wêreld toneel en owerheidsaandag dat dit selfs in verset hierteen mag wees.

Ook op universiteitsvlak kan ons nie ontkom aan die gevoel van 'n geregverdigde minderwaardigheidskompleks wat by sommige van ons geesteswetenskaplike kollegas bestaan nie. 'n Analise van die gegradueerdes by ons gradedae van die afgelope twee jaar aan ons blanke residensiële universiteite openbaar tendense wat tot nadenke stem. Waar die totale B.A.grade die B.Sc.-grade in die verhouding $3: 1$ oortref, verklein hierdie agterstand na 'n ongeveer $2: 1$ by die Honneursgraad om dan by die magistervlak om te swaai met ' $n: 3$ verhouding ten gunste van die natuurwetenskappe, wat dan verder verstewig tot $2: 1$ voorsprong by die doktorsgrade.

As ons daarby voeg dat in die oorgrote meerderheid gevalle bokant die honneursgraad die studie in die lettere en geesteswetenskappe op deeltydse basis geskied in teenstelling met die natuurwetenskappe, dan gee dit tog rede vir ernstige besinning.

Ek herhaal dat dit absoluut noodsaaklik is dat ' $n$ volk nie natuurwetenskaplik kan vorentoe gaan indien hy nie op geesteswetenskaplike vlak byhou nie. Ons kan nie met mekaar gesprek voer as ons nie langs mekaar stap nie - die een wat agterraak voel hom verplig om homself hoorbaar te maak of om motiewe aan die ander toe te dig op 'n wyse wat die een wat voor is nie altyd verwelkom of duld nie. Ek verstout my om baie van die Babelse verwarring en misverstand van ons dag, ook aan ons universiteite, aan hierdie verskynsel toe te skrywe.

C. v. d. M. Brink.

Pretoria. 